\title{
Uptake of $\alpha$-Tocopherol by the Mammary Gland But Not by White Adipose Tissue Is Dependent on Lipoprotein Lipase Activity Around Parturition and During Lactation in the Rat
}

\author{
Sonia Martínez, Coral Barbas, and Emilio Herrera
}

\begin{abstract}
This study was undertaken to test the potential role of changes in lipoprotein lipase (LPL) activity in the mammary gland and adipose tissue around parturition and lactation on the uptake of $\alpha$-tocopherol in the rat. Plasma levels of $\alpha$-tocopherol and triglycerides were higher in 20-day pregnant rats than in virgin rats, whereas its concentration was higher in the mammary gland of the former, and no differences were detected in adipose tissue between the groups. After an oral $\alpha$-tocopherol and triglyceride load, both appeared in plasma faster in pregnant rats than in virgin rats, the change being even faster for $\alpha$-tocopherol than for triglycerides. After 24 hours, both $\alpha$-tocopherol and triglycerides in $d<1.006$ lipoproteins were higher in pregnant rats than in virgin rats, LPL activity was higher in the mammary gland, and lower in adipose tissue in the former, whereas $\alpha$-tocopherol concentration also appeared higher in the mammary gland of pregnant rats, and no differences were detected between the groups in adipose tissue. At day 13 of lactation, an oral load of $\alpha$-tocopherol and triglycerides caused a higher increase of plasma $\alpha$-tocopherol levels than triglycerides, and this effect decreased when rats had their litter removed 48 hours before analysis. In these litter-removed rats, the appearance of $\alpha$-tocopherol and triglycerides in plasma was higher in $d<1.006$ lipoproteins than in lactating rats. Also, both LPL activity and $\alpha$-tocopherol concentration in the mammary gland plus milk was lower in litter-removed rats than in the lactating rats, whereas LPL in adipose tissue was higher in the former, although no difference in $\alpha$-tocopherol was found. Thus, data are consistent with the role of LPL activity in the mammary gland modulating the uptake of $\alpha$-tocopherol during pregnancy and lactation, although this is not true in adipose tissue. Copyright 2002, Elsevier Science (USA). All rights reserved.
\end{abstract}

$\mathbf{T}$ HE LIPOPROTEIN LIPASE (LPL) attached to the surface of capillary endothelium has been proposed to play a role in the delivery of $\alpha$-tocopherol to extrahepatic tissues, carried in triglyceride-rich lipoproteins, chylomicrons, and very-low-density lipoproteins (VLDL) $(d<1.006$ lipoproteins). ${ }^{1}$ In fact, subjects having LPL deficiency have both elevated plasma tocopherol in the triglyceride-rich lipoproteins ${ }^{2}$ and low tocopherol content in adipose tissue, ${ }^{3}$ suggesting an impaired delivery of tocopherol to tissues. Furthermore, muscle overexpression of LPL in transgenic mice results in increased $\alpha$-tocopherol in skeletal muscle. ${ }^{4}$ However, $\alpha$-tocopherol present in other lipoproteins may be taken up by different tissues by means of their respective uptake throughout their corresponding receptors. This seems to be especially so in the case of LDL receptors, ${ }^{3}$ although Watenabe rabbits, lacking functional LDL receptors, have normal tissue $\alpha$-tocopherol concentrations,, 5 indicating the existence of alternative mechanisms for the delivery of $\alpha$-tocopherol to tissues.

The hyperlipidemia of pregnancy involves most prominently an increase in triglycerides in all lipoprotein fractions, ${ }^{6}$ as well as the predominance of small and dense LDL particles. ${ }^{7,8}$ These small and dense LDL particles are more susceptible to oxida-

From the Faculty of Experimental and Health Sciences, University San Pablo-CEU, Madrid, Spain.

Submitted January 28, 2002; accepted March 28, 2002.

Supported by grants from the Fondo de Investigación Sanitaria, Instituto de Salud Carlos III (99/0205), Universidad San Pablo-CEU (10/99-00), and the Dirección General de Investigación, Comunidad de Madrid (0023/00).

Address reprint requests to Emilio Herrera, PhD, Universidad San Pablo-CEU, Ctra. Boadilla del Monte km 5,300, E-28668-Boadilla del Monte, Madrid, Spain.

Copyright 2002, Elsevier Science (USA). All rights reserved. 0026-0495/02/5111-0044\$35.00/0

doi:10.1053/meta.2002.34716 tion, ${ }^{9}$ which together with hypertriglyceridemia during late pregnancy, are associated with enhanced peroxidation products and antioxidant defense systems. ${ }^{10-14}$ The higher level of peroxides during normal pregnancy are accompanied by a higher level of $\alpha$-tocopherol compared with nonpregnant women. ${ }^{11-17}$ Hypertriglyceridemia in pregnant women has been associated, among other factors, with decreased LPL activity, ${ }^{6,18}$ which under the base of studies in rats, has been shown to correspond to its decrease in adipose tissue. ${ }^{19-21}$ Maternal hypertriglyceridemia rapidly ceases around parturition, ${ }^{6}$ when there is a rapid increase in the mammary gland LPL activity and mRNA expression, whereas LPL activity in adipose tissue remains low. ${ }^{22,23}$ These combined changes facilitate an enhanced uptake of circulating triglycerides by the mammary gland instead of being stored in adipose tissue. ${ }^{24} \mathrm{~A}$ similar fate could be proposed for $\alpha$-tocopherol, because adipose tissue constitutes its main store in the body, ${ }^{25}$ shows the highest LPL activity under nonpregnant conditions, ${ }^{26}$ and also $\alpha$-tocopherol becomes highly enhanced in the mammary gland around parturition, as suggested by its increased concentration in colostrum as compared with mature milk. ${ }^{27-29}$ Therefore, the present study was undertaken to determine the potential relationship between changes in LPL activity in adipose tissue and the mammary gland as compared with their content of $\alpha$-tocopherol during late gestation and midlactation in the rat. Because litter separation at midlactation causes an abrupt and opposite change in LPL activity in the mammary gland and adipose tissue, ${ }^{30-32}$ this strategy was also used to determine its effect on $\alpha$-tocopherol content in these tissues. Results show that around parturition and during lactation in the rat, changes in $\alpha$-tocopherol content in the mammary gland correlate with tissue LPL activity, suggesting a direct relationship, whereas this is not the case in adipose tissue, where major changes in LPL activity are not followed by parallel changes in its content of $\alpha$-tocopherol. 


\section{MATERIALS AND METHODS}

\section{Animals}

Female Wistar rats from our animal quarters were fed a standard diet (B\&K Universal, Barcelona, Spain) and housed under controlled light and temperature conditions (12-hour light/dark cycle; $22^{\circ} \mathrm{C} \pm 1{ }^{\circ} \mathrm{C}$ ). The experimental protocol was approved by the Animal Research Committee of the Universidad San Pablo-CEU in Madrid, Spain. Rats were mated when they weighed 180 to $190 \mathrm{~g}$, and the day in which spermatozoids were found in vaginal smears was considered day 0 of pregnancy. Pregnant rats were divided into 3 groups. In the first group, at day 19 of pregnancy, rats were subjected to an $\alpha$-tocopheroltriglyceride load test as follows: an aliquot of blood was collected from the tail into receptacles containing $\mathrm{Na}_{2}$-EDTA (time 0 ) and a mixture of $10 \mathrm{mg} \mathrm{dL}-\alpha$-tocopherol, $100 \mathrm{mg}$ triolein, and $10 \mathrm{mg}$ Tween- 80 suspended in $0.5 \mathrm{~mL}$ saline was given orally by gavage. Blood aliquots of no more than $100 \mu \mathrm{L}$ were collected as above at $0.5,1,2,4,6$, and 8 hours, and at 24 hours, rats were decapitated and blood from the neck wound collected into receptacles containing $\mathrm{Na}_{2}$-EDTA. Mammary glands and lumbar adipose tissue were rapidly excised and placed into liquid nitrogen and kept at $-80^{\circ} \mathrm{C}$ until processed. Sex- and agematched virgin rats were studied in parallel. In the second group, pregnant rats not receiving any treatment were allowed to deliver, at which time litters were adjusted to 8 pups per dam. On the 12th day of lactation, pups were removed from half of the dams, and on day 13 of lactation, all the rats were subjected to the same oral $\alpha$-tocopheroltriglyceride load test as above and were decapitated at its completion, corresponding to day 14 of lactation. In the third group, untreated pregnant rats were allowed to deliver, litters adjusted to 8 pups per dam, and milk yield was estimated from pup weight and weight gain on day 13 to 14 of lactation as previously described. ${ }^{33}$ On day 14 of lactation, after being separated from their litters, dams were anesthetized with $0.5 \mathrm{~mL} / 200 \mathrm{~g}$ of a cocktail containing $9 \mathrm{mg}$ ketamine (Imalgene 500; Rhone Merieux, Lyon, France) and $0.25 \mathrm{mg}$ chlorpromazine (Largactil; Rhone Poulenc, Madrid, Spain) administered intraperitoneally. Rats were injected intraperitoneally with $0.25 \mathrm{~mL} / 200 \mathrm{~g}$ of a solution of oxytocin (2,000 IU/L Syntocimón; Novartis Farmaceutica, Barcelona, Spain), and milk was obtained with gentle hand stripping of the teats. Milk was immediately kept at $-80^{\circ} \mathrm{C}$ until processed.

\section{Processing of Samples}

Fresh plasma aliquots were subjected to sequential ultracentrifugation for lipoprotein isolation as previously described. ${ }^{34}$ The isolated lipoprotein fractions and whole plasma aliquots were kept at $-80^{\circ} \mathrm{C}$ until processed. $\alpha$-Tocopherol was measured in lipoprotein fractions, plasma, milk, mammary gland, and lumbar adipose tissue by highperformance liquid chromatography (HPLC) according to methods previously described. ${ }^{27,35}$ Triglycerides and cholesterol were measured in plasma and lipoprotein fractions with commercial kits (\#B-7648 and \#B-7576, respectively; Meranini Diagnostics, Florence, Italy). LPL activity was measured in acetone-diethyl ether delipidated tissue samples, as previously described. ${ }^{36,37}$

\section{Statistical Analysis}

Data are expressed as means \pm SEM. Statistical comparisons were made with analysis of variance (ANOVA) followed by the Tukey test with 95\% confidence limits, using Systat program (Systat, Evanston, IL). The relationship between variables was determined by Pearson correlation coefficient using the Systat program (Systat).

\section{RESULTS}

Effect of Pregnancy on $\alpha$-Tocopherol Concentration in Plasma, Adipose Tissue, and Mammary Gland

Plasma level of both $\alpha$-tocopherol and triglycerides were higher in 20-day pregnant rats than in virgin rats, the difference disappearing when these variables were expressed as the $\alpha$-tocopherol-triglyceride ratio (Table 1). The concentration of $\alpha$-tocopherol in adipose tissue did not differ between pregnant and virgin rats, whereas in the mammary gland, it was significantly higher in the former (Table 1).

\section{Response to Oral $\alpha$-Tocopherol and Triglyceride Load}

As shown in Fig 1, oral administration of $\alpha$-tocopherol (10 $\mathrm{mg} / \mathrm{rat})$ and triglyceride $(100 \mathrm{mg}$ trioleine/rat $)$ to virgin rats caused a significant increase in both $\alpha$-tocopherol and triglyceride plasma levels from 1 hour after the treatment, which in the case of $\alpha$-tocopherol, lasted up to 24 hours and, in the case of triglycerides, up to 2 hours, after which values returned to those found at 0 time. A similar change, although more marked, was found in the case of the 19-day pregnant rats, in which plasma levels of $\alpha$-tocopherol attained higher values than those of virgin rats at $0,2,4,6,8$, and 24 hours after the treatment and those of triglycerides were significantly higher than those of virgins at all time points studied.

When $\alpha$-tocopherol and triglycerides were determined in major plasma lipoprotein fractions at 24 hours after their oral administration, a different distribution was found between the 2 groups. In virgin rats, the $\alpha$-tocopherol values were distributed in the same range among the different lipoprotein fractions, whereas triglycerides were mainly present in $d<1.006$ lipoproteins (Table 2). However, in pregnant rats, the highest lipoprotein content of both $\alpha$-tocopherol and triglycerides was

Table 1. $\alpha$-Tocopherol Concentration in Plasma, Lumbar Adipose Tissue, and Mammary Gland in Virgin and 20-Day Pregnant Rats

\begin{tabular}{lccc}
\hline & Virgin & Pregnant & $P^{*}$ \\
\hline Plasma & & & $<.01$ \\
$\alpha$-Tocopherol $(\mu \mathrm{g} / \mathrm{dL})$ & $205 \pm 13$ & $383 \pm 25$ & $<.001$ \\
$\quad$ Triglycerides $(\mathrm{mg} / \mathrm{dL})$ & $70.8 \pm 10.3$ & $147 \pm 8$ & $\mathrm{NS}$ \\
$\alpha$-Tocopherol/triglycerides $(\mu \mathrm{g} / \mathrm{mg})$ & $2.2 \pm 0.3$ & $2.5 \pm 0.4$ & $\mathrm{NS}$ \\
Adipose tissue & $19.4 \pm 3.4$ & $12.0 \pm 1.5$ & $<.001$ \\
$\alpha$-Tocopherol $(\mu \mathrm{g} / \mathrm{g})$ & $52.8 \pm 3.1$ & $107 \pm 10$ & \\
Mammary gland & & \\
$\alpha$-Tocopherol $(\mu \mathrm{g} / \mathrm{g})$ & & & \\
\hline
\end{tabular}

NOTE. Values are means \pm SE of 5 rats per group.

* Statistical comparison between virgin and pregnant rats (NS, not significant). 


\section{$\alpha$-TOCOPHEROL}

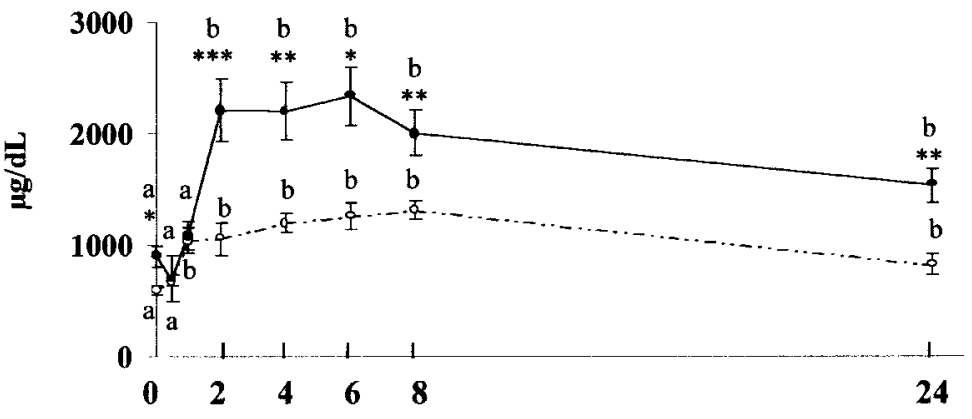

Time (h)
TRIGLYCERIDES

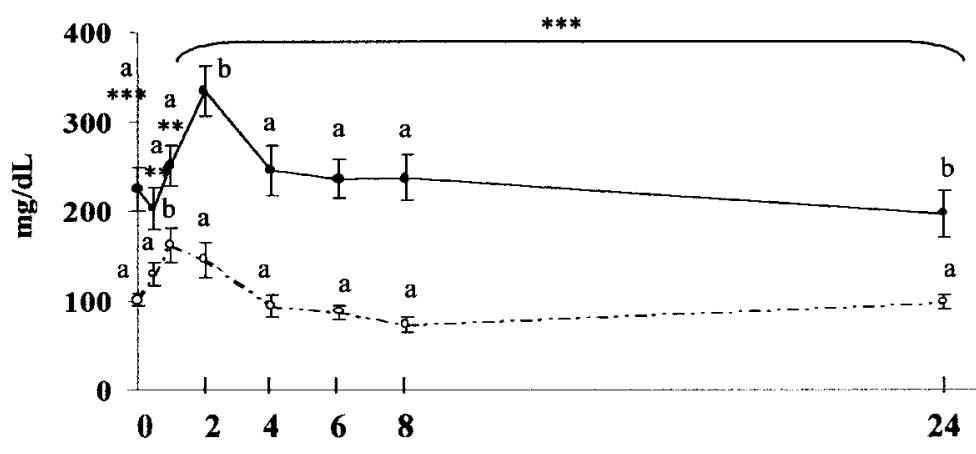

Fig 1. Plasma $\alpha$-tocopherol and triglyceride concentrations after an oral $\alpha$-tocopherol $(10 \mathrm{mg})$ and triolein $(100 \mathrm{mg})$ load in virgin $(O)$ and 19-day pregnant rats $(\bullet)$. Asterisks correspond to statistical differences between pregnant and virgin rats ${ }^{*} P<.05$, $\left.{ }^{* *} P<.01,{ }^{* * *} P<.001\right)$, whereas the letters indicate statistical differences among different time points for the same experimental group (different letters indicate statistical differences) using Tukey's test. $\mathrm{N}=\mathbf{6}$ to 8 rats per group. found in $d<1.006$ lipoproteins, and their difference with values in virgin rats was statistically significant. The $\alpha$-tocopherol/triglyceride ratios, however, did not differ between pregnant and virgin rats, and values were always highest in highdensity lipoprotein (HDL) followed by low-density lipoprotein (LDL) and much lower in $d<1.006$ lipoproteins (Table 2).

Twenty-four hours after the $\alpha$-tocopherol and triglyceride load, corresponding to day 20 of gestation in the case of pregnant rats, LPL activity in the mammary gland was significantly higher in pregnant than in virgin rats, whereas the opposite change was found for LPL activity in lumbar adipose tissue, which the value in pregnant rats was significantly lower than in virgin rats (Table 3). The concentration of $\alpha$-tocopherol in adipose tissue, but not in the mammary gland, appeared significantly higher 24 hours after the oral administration of $\alpha$-tocopherol and triolein (Table 3) than in rats not receiving

Table 2. $\alpha$-Tocopherol and Triglycerides in Plasma Lipoproteins of Virgin and 20-Day Pregnant Rats 24 Hours After Oral Administration of

\begin{tabular}{|c|c|c|c|}
\hline & $\begin{array}{c}\alpha \text {-Tocopherol } \\
(\mu \mathrm{g} / \mathrm{dL})\end{array}$ & $\begin{array}{l}\text { Triglycerides } \\
(\mathrm{mg} / \mathrm{dL})\end{array}$ & $\begin{array}{c}\alpha \text {-Tocopherol/Triglycerides } \\
(\mu \mathrm{g} / \mathrm{mg})\end{array}$ \\
\hline \multicolumn{4}{|c|}{$d<1.006$ Lipoproteins } \\
\hline Virgin & $296 \pm 22$ & $80.2 \pm 19.2$ & $6.5 \pm 2.5$ \\
\hline Pregnant & $1,014 \pm 171$ & $245 \pm 30$ & $3.9 \pm 0.4$ \\
\hline$P^{*}$ & $<.05$ & $<.01$ & NS \\
\hline \multicolumn{4}{|l|}{ LDL } \\
\hline Virgin & $247 \pm 18$ & $8.2 \pm 1.9$ & $33.9 \pm 10.9$ \\
\hline Pregnant & $232 \pm 65$ & $8.2 \pm 0.4$ & $30.0 \pm 8.9$ \\
\hline$P$ & NS & NS & NS \\
\hline \multicolumn{4}{|l|}{ HDL } \\
\hline Virgin & $312 \pm 11$ & $3.1 \pm 0.2$ & $110 \pm 4$ \\
\hline Pregnant & $247 \pm 98$ & $4.8 \pm 0.6$ & $64.2 \pm 28.1$ \\
\hline$P$ & NS & $<.05$ & NS \\
\hline
\end{tabular}

NOTE. Rats were given orally by gavage a suspension containing $10 \mathrm{mg} / \mathrm{dL} \alpha$-tocopherol, $100 \mathrm{mg}$ triolein, and $10 \mathrm{mg}$ Tween-80 in saline. They were decapitated 24 hours later, corresponding to day 20 of gestation in the pregnant rats. Values are means \pm SE of 6 rats per group.

*Corresponds to the statistical comparisons between virgin and pregnant rats (NS, not significant, $P>.05$ ). 
Table 3. LPL Activity and $\alpha$-Tocopherol, in Mammary Gland and Lumbar Adipose Tissue of Virgin and 20-Day Pregnant Rats 24 Hours After Oral Administration of $\alpha$-Tocopherol $(10 \mathrm{mg})$ and Triolein $(100 \mathrm{mg})$

\begin{tabular}{lccc}
\hline & Virgin & Pregnant & $P^{*}$ \\
\hline LPL activity in mammary gland (pkat/g) & $167 \pm 22$ & $1,959 \pm 206$ & $<.001$ \\
LPL activity in adipose tissue $(\mathrm{pkat} / \mathrm{g})$ & $1,408 \pm 172$ & $627 \pm 125$ & $<.01$ \\
$\alpha$-Tocopherol in mammary gland $(\mu \mathrm{g} / \mathrm{g})$ & $68.4 \pm 9.6$ & $132 \pm 25$ & $<.05$ \\
$\alpha$-Tocopherol in adipose tissue $(\mu \mathrm{g} / \mathrm{g})$ & $37.2 \pm 6.0$ & $36.2 \pm 2.1$ & $\mathrm{NS}$ \\
\hline
\end{tabular}

NOTE. Rats were given orally by gavage a suspension containing $10 \mathrm{mg} / \mathrm{dL} \alpha$-tocopherol, $100 \mathrm{mg}$ triolein, and $10 \mathrm{mg}$ Tween-80 in saline. They were decapitated 24 hours later, corresponding to day 20 of gestation in the pregnant rats. Values are means \pm SE of 6 rats per group.

${ }^{*}$ Corresponds to the statistical comparisons between virgin and pregnant rats (NS, not significant, $P>.05$ ).

these treatments (Table 1) $(P<.05)$. However, whereas the concentration of $\alpha$-tocopherol in the mammary gland was significantly higher in pregnant rats than in virgin rats 24 hours after the oral $\alpha$-tocopherol and triglyceride loads, no difference was found between the 2 groups in its concentration in adipose tissue (Table 3), as it occurred in rats not receiving any treatment (Table 1). Those differences in the $\alpha$-tocopherol concentration in the mammary gland between the 2 groups become even greater when expressed per total gland weight $(1,339 \pm$ $212 \mu \mathrm{g}$ in pregnant rats and $135 \pm 21 \mu \mathrm{g}$ in virgin rats, $P<$ .001 ), whereas no difference was found when values in the lumbar adipose tissue were corrected by total tissue weight (data not shown).

When rats were studied at day 14 after parturition, those that had their litter removed 48 hours before analysis showed similar plasma $\alpha$-tocopherol levels than lactating rats, although distribution among the different lipoproteins greatly differed between the 2 groups, being significantly higher in $d<1.006$ lipoproteins and lower in LDL in the litter-removed rats than in the lactating rats (Table 4). Plasma triglycerides were significantly higher in the litter-removed rats than in the lactating ones, the difference corresponding to a higher triglyceride concentration in all lipopoprotein fractions (Table 4). This different change in plasma $\alpha$-tocopherol and triglyceride con- centrations also modified their ratio, being lower in total plasma, LDL, and HDL of litter-removed rats than in lactating rats, with no difference in $d<1.006$ lipoproteins (Table 4). As shown in Table 5, in these same animals, LPL activity in the mammary gland plus milk appeared much lower in the litterremoved rats than in the lactating rats, whereas LPL activity in the adipose tissue appeared significantly higher in the latter than in the former group. However, whereas $\alpha$-tocopherol in the mammary gland plus milk was significantly lower in the litter-removed rats than in those kept lactating, no differences were found in adipose tissue between the 2 groups (Table 5). Differences in $\alpha$-tocopherol content in the mammary gland plus milk between lactating rats and litter-removed rats become greater when expressed per total mammary gland plus that present in total milk per day, giving values of 1,309 $\pm 92 \mu \mathrm{g}$ in the former group and $982 \pm 22 \mu \mathrm{g}$ in the latter $(P<.01)$, whereas values of total lumbar adipose tissue remain similar between the 2 groups (data not shown).

Some lactating and litter-removed rats were also subjected to the oral $\alpha$-tocopherol $(10 \mathrm{mg})$ and triglyceride $(100 \mathrm{mg})$ load at day 13 after parturition. As shown in Fig 2, both plasma $\alpha$-tocopherol and triglycerides increased more intensely shortly after the oral load in the litter-removed rats than in the lactating rats to return to basal values at 8 hours in the case of $\alpha$-to-

Table 4. $\alpha$-Tocopherol and Triglycerides in Plasma Lipoproteins in Lactating Rats at Day 14 After Delivery

\begin{tabular}{lccc}
\hline & $\begin{array}{c}\alpha \text {-Tocopherol } \\
(\mu \mathrm{g} / \mathrm{dL})\end{array}$ & $\begin{array}{c}\text { Triglycerides } \\
(\mathrm{mg} / \mathrm{dL})\end{array}$ & $\begin{array}{c}\alpha \text {-Tocopherol/Triglycerides } \\
(\mu \mathrm{g} / \mathrm{mg})\end{array}$ \\
\hline Plasma & $823 \pm 103$ & & $18.7 \pm 2.2$ \\
$\quad$ Lactating & $853 \pm 70$ & $45.2 \pm 1.8$ & $5.3 \pm 0.5$ \\
Litter removed 48 h & $\mathrm{NS}$ & $164 \pm 7$ & $<.001$ \\
$P^{*}$ & & $<.001$ & $2.0 \pm 0.2$ \\
d $<$ 1.006 Lipoprotein & $70.7 \pm 5.7$ & $37.6 \pm 2.7$ & $2.2 \pm 0.4$ \\
Lactating & $298 \pm 47$ & $135 \pm 2$ & $\mathrm{NS}$ \\
Litter removed 48 h & $<.001$ & $<.001$ & $133 \pm 36$ \\
$P$ & & & $14.6 \pm 0.8$ \\
LDL & $224 \pm 43$ & $2.6 \pm 0.7$ & $<.01$ \\
Lactating & $80.9 \pm 7.3$ & $5.7 \pm 0.7$ & $1,288 \pm 450$ \\
Litter removed 48 h & $<.01$ & $<.05$ & $156 \pm 14$ \\
$P$ & & & $<.05$
\end{tabular}

NOTE. Litters were removed in some lactating rats 48 hours prior to the study (from the 12th day after delivery), and all rats were studied at day 14 after delivery. Values correspond to means \pm SE of 6 to 8 rats per group.

* Statistical comparisons between lactating rats and those whose pups were removed 48 hours earlier (NS, not significant). 
Table 5. LPL Activity and $\alpha$-Tocopherol, in Mammary Gland and Adipose Tissue in Lactating Rats at Day 14 After Delivery

\begin{tabular}{|c|c|c|c|}
\hline & Lactating & $\begin{array}{l}\text { Litter Removed } \\
48 \text { Hours }\end{array}$ & $P^{*}$ \\
\hline LPL activity in mammary gland + milk (pkat/g or $\mathrm{mL}$ ) & $1,970 \pm 182$ & $159 \pm 16$ & $<.001$ \\
\hline LPL activity in adipose tissue (pkat/g) & $599 \pm 124$ & $2,615 \pm 130$ & $<.001$ \\
\hline$\alpha$-Tocopherol in mammary gland + milk $(\mu \mathrm{g} / \mathrm{g}$ or $\mathrm{mL})$ & $71.4 \pm 4.9$ & $46.3 \pm 1.0$ & $<.01$ \\
\hline$\alpha$-Tocopherol in adipose tissue $(\mu \mathrm{g} / \mathrm{g})$ & $37.8 \pm 4.6$ & $41.3 \pm 2.1$ & NS \\
\hline
\end{tabular}

NOTE. Litters were removed in some lactating rats 48 hours prior to the study (from the 12th day after delivery) and all rats were studied at day 14 after delivery. Values correspond to means \pm SE of 6 to 8 rats per group.

* Statistical comparisons between lactating rats and those whose pups were removed 48 hours earlier (NS, not significant).

copherol and at 4 hours in the case of triglycerides, values in the latter remaining always higher than in the former. As shown in Table 6, at 24 hours after the oral load, $\alpha$-tocopherol was higher in $d<1.006$ lipoproteins and lower in HDL in the litter-removed rats than in the lactating rats, whereas enhanced plasma triglycerides in the former specifically corresponded to those present in $d<1.006$ lipoproteins, without any difference in the other lipoproteins. The $\alpha$-tocopherol/triglyceride ratio did not differ among the lipoprotein fractions (Table 6).

As shown in Table 7, 24 hours after the oral $\alpha$-tocopherol and triglyceride load, LPL activity in the mammary gland plus milk remained lower and in adipose tissue higher in the litterremoved rats as compared with lactating rats. Furthermore, although the $\alpha$-tocopherol concentration in the mammary gland changed in parallel to LPL activity, being lower in litterremoved rats than in lactating rats, it did not differ between the 2 groups in adipose tissue.
When individual values of all rats studied were considered, a significant linear correlation was found between LPL activity and $\alpha$-tocopherol concentration in the mammary gland plus milk expressed per gram of tissue weight (LPL $=14.82 \alpha$-tocopherol $+15.7, r=.53, \mathrm{n}=51, P<.001)$, whereas this was not the case in adipose tissue (LPL $=17.98 \alpha$-tocopherol + $584.4, r=.25, \mathrm{n}=51$, not significant), and a similar relationship was found when values from each of the experiments were considered separately (data not shown).

\section{DISCUSSION}

The present results show that during late pregnancy in the rat, enhanced plasma $\alpha$-tocopherol parallel triglyceride levels, and that after an oral load with both $\alpha$-tocopherol and triglycerides, both components become highly enhanced in $d<1.006$ lipoproteins. Furthermore, whereas the tissue concentration of
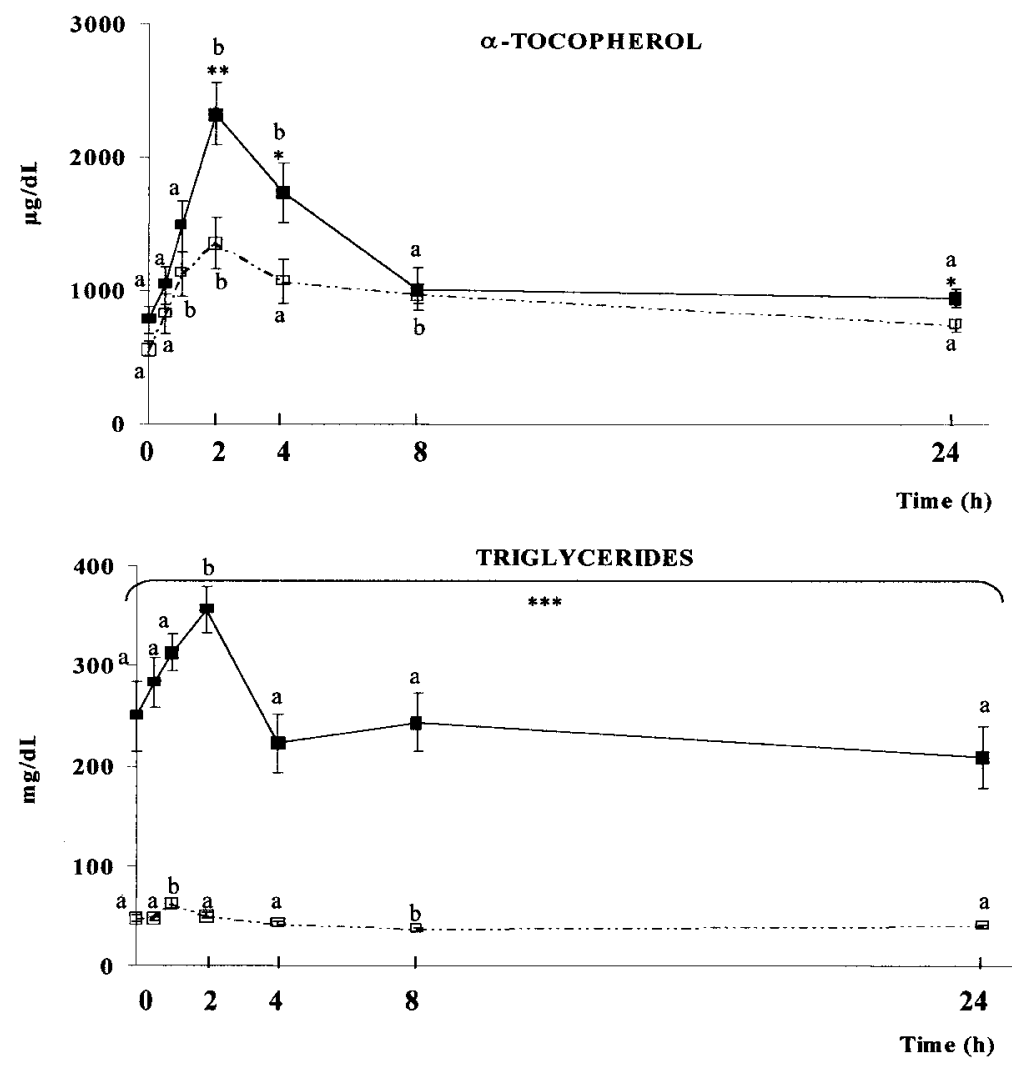

Fig 2. Plasma $\alpha$-tocopherol and triglyceride concentrations after an oral $\alpha$-tocopherol $(10 \mathrm{mg})$ and triolein $(100 \mathrm{mg}$ ) load in 14-day lactating rats $(\square)$ and litter-removed rats (litter removed the previous 48 hours) (口). Asterisks correspond to statistical difference between litter-removed and lactating rats $\left({ }^{*} \boldsymbol{P}<.05,{ }^{*} \boldsymbol{P}<.01,{ }^{* *} \boldsymbol{P}<.001\right)$, whereas letters indicate statistical differences among different time points for the same experimental group (different letters indicate significant statistical differences) using Tukey's test. $\mathbf{N}=\mathbf{8}$ rats per group. 
Table 6. $\alpha$-Tocopherol and Triglycerides in Plasma Lipoproteins in Lactating Rats at Day 14 After Delivery 24 Hours After Oral Administration of $\alpha$-Tocopherol (10 mg) and Triolein (100 mg)

\begin{tabular}{lccc}
\hline & $\begin{array}{c}\alpha \text {-Tocopherol } \\
(\mu \mathrm{g} / \mathrm{dL})\end{array}$ & $\begin{array}{c}\text { Triglycerides } \\
(\mathrm{mg} / \mathrm{dL})\end{array}$ & $\begin{array}{c}\alpha \text {-Tocopherol/Triglycerides } \\
(\mu \mathrm{g} / \mathrm{mg})\end{array}$ \\
\hline $\mathrm{d}<$ 1.006 Lipoprotein & & & $2.2 \pm 0.1$ \\
Lactating & $86.3 \pm 4.2$ & $40.5 \pm 2.2$ & $2.8 \pm 0.3$ \\
Litter removed 48 hours & $402 \pm 40$ & $143 \pm 8$ & $\mathrm{NS}$ \\
$P^{*}$ & $<.001$ & $<.001$ & $27.4 \pm 2.3$ \\
LDL & $141 \pm 15$ & $5.3 \pm 0.6$ & $19.8 \pm 3.7$ \\
Lactating & $120 \pm 16$ & $6.6 \pm 0.8$ & $\mathrm{NS}$ \\
Litter removed 48 hours & $\mathrm{NS}$ & $\mathrm{NS}$ & $241 \pm 32$ \\
$P$ & & $3.0 \pm 0.4$ & $283 \pm 27$ \\
HDL & $677 \pm 41$ & $1.9 \pm 0.9$ & $\mathrm{NS}$ \\
Lactating & $526 \pm 50$ & $\mathrm{NS}$ & \\
Litter removed 48 hours & $<.05$ & & \\
$P$ & & & \\
\hline
\end{tabular}

NOTE. At day 12 of lactation, pups were removed from same dams and on day 13 of lactation, all rats were given orally by gavage a suspension containing $10 \mathrm{mg} / \mathrm{dL} \alpha$-tocopherol, $100 \mathrm{mg}$ triolein, and $10 \mathrm{mg}$ Tween-80 in saline, and they were decapitated 24 hours later, corresponding to day 14 of lactation. Values are means \pm SE of 6 to 8 rats per group.

${ }^{*}$ Corresponds to the statistical comparisons between lactating and litter-removed rats (NS, not significant, $P>.05$ ).

$\alpha$-tocopherol parallels LPL activity in the mammary gland, which was higher in pregnant rats than in virgin rats, this was not the case in lumbar adipose tissue, in which LPL activity was higher in the latter group, but $\alpha$-tocopherol did not differ between them. In 48-hour litter-removed rats at midlactation, mammary gland LPL activity was greatly decreased, whereas lumbar adipose tissue LPL activity was enhanced, and whereas $\alpha$-tocopherol concentration declined in parallel to LPL activity in the mammary gland, it did not change in adipose tissue; the results were similar when animals were studied under either basal conditions or after the $\alpha$-tocopherol and triglyceride load. These findings indicate that although during late pregnancy and midlactation, the mammary gland LPL activity plays an important role in the availability of $\alpha$-tocopherol in the tissue, major changes in adipose tissue LPL activity do not affect the amount of $\alpha$-tocopherol being taken by the tissue. It must then be claimed that in adipose tissue the uptake of $\alpha$-tocopherol must depend on other factors independent of LPL changes, presumably lipoprotein receptors.

The present findings also show the efficient capability of the late pregnant rat to absorb dietary $\alpha$-tocopherol. In fact, despite receiving the same oral dose of $\alpha$-tocopherol and triglycerides per rat (ie, lower in pregnant rats when corrected by body weight), the increase in the plasma $\alpha$-tocopherol level was higher in pregnant rats, the effect being even greater for plasma $\alpha$-tocopherol than for triglycerides at short times after the load, producing an increase of the $\alpha$-tocopherol/triglyceride ratio in $d<1.006$ lipoproteins. An enhanced efficiency for intestinal absorption of triglycerides during late pregnancy in the rat has already been reported, ${ }^{24}$ and thus the present study supports that such effect seems to be even more pronounced for $\alpha$ tocopherol, which must contribute to the consistent increase in plasma $\alpha$-tocopherol levels seen during late pregnancy in women, ${ }^{13,38}$ and as seen here, in untreated late pregnant rats. Also, consistent with the enhanced $\alpha$-tocopherol absorption in late pregnant rats was the fact that its increase in plasma mainly corresponded to that present in $d<1.006$ lipoproteins, in parallel with the changes found in plasma triglycerides.

Except for the liver uptake of $\alpha$-tocopherol present in chylomicron remnants, the fate of plasma $\alpha$-tocopherol in triglyceride-rich lipoproteins would be extrahepatic tissues uptake where the highest LPL activity is located, such as adipose tissue under nonpregnant conditions and the mammary gland during late pregnancy. However, the stable concentration of $\alpha$-tocopherol in lumbar adipose tissue in virgin and pregnant rats even after its oral load found here together with the lower LPL activity in the latter would suggest that changes in LPL activity in adipose tissue do not affect the $\alpha$-tocopherol uptake of this

Table 7. LPL Activity and $\alpha$-Tocopherol in Mammary Gland and Adipose Tissue in Dams at Day 14 After Delivery and 24 Hours After $\alpha$-Tocopherol and Triglyceride Load

\begin{tabular}{|c|c|c|c|}
\hline & Lactating & $\begin{array}{l}\text { Litter Removed } \\
48 \text { Hours }\end{array}$ & $P^{*}$ \\
\hline LPL activity in mammary gland + milk (pkat/g or $\mathrm{mL}$ ) & $2,494 \pm 163$ & $329 \pm 74$ & $<.001$ \\
\hline LPL activity in adipose tissue (pkat/g) & $530 \pm 65$ & $2,731 \pm 280$ & $<.001$ \\
\hline$\alpha$-Tocopherol in mammary gland $+\operatorname{milk}(\mu \mathrm{g} / \mathrm{g}$ or $\mathrm{mL})$ & $93.8 \pm 5.4$ & $50.5 \pm 2.3$ & $<.001$ \\
\hline$\alpha$-Tocopherol in adipose tissue $(\mu \mathrm{g} / \mathrm{g})$ & $41.1 \pm 3.0$ & $43.6 \pm 0.4$ & NS \\
\hline
\end{tabular}

NOTE. At day 12 of lactation, pups were removed from same dams, and on day 13 of lactation, all rats were given orally by gavage a suspension containing $10 \mathrm{mg} / \mathrm{dL} \alpha$-tocopherol, $100 \mathrm{mg}$ triolein, and $10 \mathrm{mg}$ Tween-80 in saline. They were decapitated 24 hours later, corresponding to day 14 of lactation. Values are means \pm SE of 6 to 8 rats per group.

${ }^{*}$ Corresponds to the statistical comparisons between lactating and litter-removed rats (NS, not significant, $P>.05$ ). 
tissue. This finding is contrary to the reduction in VLDL triglyceride hydrolysis and fatty acid uptake previously seen in adipose tissue of late pregnant rats, ${ }^{20}$ suggesting that different to what occurs with triglycerides in triglyceride-rich lipoproteins, the uptake of $\alpha$-tocopherol by this tissue is independent of LPL activity. However, this is different to what it occurs in the mammary gland, where a parallel change in both LPL activity and $\alpha$-tocopherol content under basal conditions and after the oral $\alpha$-tocopherol load was found, suggesting a direct relationship between these 2 variables.

Similar conclusions may be attained when analyzing the data found at midlactation in the litter removed rat. In agreement with previous reports, ${ }^{30,39}$ LPL activity greatly declined in the mammary gland, whereas it increased in lumbar adipose tissue. Plasma triglyceride levels greatly increased in these animals. This effect is in agreement with previous reports, although litter removal was performed within 12 hours, ${ }^{31}$ a shorter period of time than the 48 hours used here. This increase may be justified by the greater decline in mammary gland LPL activity, which is greater than the degree of its increase in adipose tissue. This change affected the plasma lipoprotein profile in the rats, as seen by the enhanced concentration in both $\alpha$-tocopherol and triglycerides in $d<1.006$ lipoproteins, the increase in both LDL and HDL triglycerides and the decline in $\alpha$-tocopherol in LDL causing a significant reduction in the $\alpha$-tocopherol/triglyceride ratio in both LDL and HDL. It also decreased the concentration of $\alpha$-tocopherol in the mammary gland under both basal conditions and after the oral $\alpha$-tocopherol-triglyceride load, showing that $\alpha$-tocopherol uptake by the gland depends on LPL activity. The increase of LPL in lumbar adipose tissue of the litter-removed rats, however, does not modify the amount of $\alpha$-tocopherol in the tissue under either basal conditions or after an oral load of $\alpha$-tocopherol. This finding together with those mentioned above in which a decline in adipose tissue LPL activity as that seen during late pregnancy did not modify the amount of $\alpha$-tocopherol in this tissue is consistent with the notion that unlike what occurs in the mammary gland, the uptake of $\alpha$-tocopherol by adipose tisue is independent of LPL activity, and other mechanisms, such as the lipoprotein receptors, may be claimed as a major way for this tissue to take up $\alpha$-tocopherol from circulating lipoproteins.

The effect of litter removal on plasma lipoprotein profile, with a specific increase in the content of both $\alpha$-tocopherol and triglycerides in $d<1.006$ lipoproteins, which become even further augmented 24 hours after the $\alpha$-tocopherol-triglyceride load, supports a major role of the decline in the mammary gland LPL delaying the catabolism of these triglyceride-rich lipoproteins. A similar interaction was previously seen around parturition in the rat, in which the increase in mammary LPL activity was found to actively contribute to the decline in plasma triglycerides. ${ }^{22}$ Thus, the present results show that, contrary to what occurs in adipose tissue, where LPL activity does not seem to play a role in the uptake of circulating $\alpha$-tocopherol, during late pregnancy and lactation, changes in LPL activity in the mammary gland greatly modulate the uptake of $\alpha$-tocopherol by the gland, also affecting the lipoprotein profile, and most likely, the fate of circulating $\alpha$-tocopherol and triglycerides in triglyceride-rich lipoproteins.

\section{ACKNOWLEDGMENT}

The authors thank Milagros Morante for excellent technical assistance and Dr Beatriz Ramos for editorial help.

\section{REFERENCES}

1. Traber MG, Olivecrona T, Kayden HJ: Bovine milk lipoprotein lipase transfers tocopherol to human fibroblasts during triglyceride hydrolysis in vitro. J Clin Invest 75:1729-1734, 1985

2. Traber MG, Burton GW, Hughes L, et al: Discrimination between forms of vitamin $\mathrm{E}$ by humans with and without genetic abnormalities of lipoprotein metabolism. J Lipid Res 33:1171-1182, 1992

3. Traber MG, Kayden HJ: Vitamin E is delivered to cells via the high affinity receptor for low density lipoprotein. Am J Clin Nutr 40:747-751, 1984

4. Sattler W, Levak-Frank S, Radner H, et al: Muscle-specific overexpression of lipoprotein lipase in transgenic mice results in increased $\alpha$-tocopherol levels in skeletal muscle. Biochem J 318:15-19, 1996

5. Cohn W, Kuhn H: The role of the low-density lipoprotein receptor for $\alpha$-tocopherol delivery to tissues. Ann N Y Acad Sci 570:61-71, 1989

6. Alvarez JJ, Montelongo A, Iglesias A, et al: Longitudinal study on lipoprotein profile, high-density lipoprotein subclass, and postheparin lipases during gestation in women. J Lipid Res 37:299308, 1996

7. Silliman K, Shore V, Forte TM: Hypertriglyceridemia during late pregnancy is associated with the formation of small dense low-density lipoproteins and the presence of large buoyant high-density lipoproteins. Metabolism 43:1035-1041, 1994

8. Sattar N, Greer IA, Louden J, et al: Lipoprotein subfraction changes in normal pregnancy: Threshold effect of plasma triglyceride on appearance of small, dense low-density lipoprotein. J Clin Endocrinol Metab 82:2483-2491, 1997

9. de-Graaf J, Hak LH, Hectors MP, et al: Enhanced susceptibility to in vitro oxidation of the dense low density lipoprotein subfraction in healthy subjects. Arterioscler Thromb Vasc Biol 11:298-306, 1991

10. Carone D, Loverro G, Greco P, et al: Lipid peroxidation products and antioxidant enzymes in red blood cells during normal and diabetic pregnancy. Eur J Obstet Gynecol Reprod Biol 51:103-109, 1993

11. Uotila JT, Tuimala R, Aarnio T, et al: Lipid peroxidation products, selenium-dependent glutathione peroxidase and vitamin $\mathrm{E}$ in normal pregnancy. Eur J Obstet Gynecol Reprod Biol 42:95-100, 1991

12. Wang YP, Walsh SW, Guo JD, et al: Maternal levels of prostacyclin, thromboxane, vitamin E, and lipid peroxides throughout normal pregnancy. Am J Obstet Gynecol 165:1690-1694, 1991

13. Morris JM, Gopaul NK, Endresen MJR, et al: Circulating markers of oxidative stress are raised in normal pregnancy and pre-eclampsia. Br J Obstet Gynaecol 105:1195-1199, 1998

14. Walsh SW: The role of fatty acid peroxidation and antioxidant status in normal pregnancy and in pregnancy complicated by preeclampsia. World Rev Nutr Diet 76:114-118, 1994

15. Mino M: Vitamin E status in pregnancy and newborn infants with respect to red blood cell tocopherol, in Berger H (ed): Vitamins and Minerals in Pregnancy and Lactation. New York, NY, Raven, 1988, pp 59-60

16. Oostenbrug GS, Mensink RP, Al MDM, et al: Maternal and neonatal plasma antioxidant levels in normal pregnancy, and the relationship with fatty acid unsaturation. Br J Nutr 80:67-73, 1998

17. De Vriese SR, Dhont M, Christophe AB: Oxidative stability of low-density lipoproteins and vitamin E levels increase in maternal blood during normal pregnancy. Lipids 36:361-366, 2001 
18. Kinnunen PK, Unnérus HA, Ranta T, et al: Activities of postheparin plasma lipoprotein lipase and hepatic lipase during pregnancy and lactation. Eur J Clin Invest 10:469-474, 1980

19. Hamosh M, Clary TR, Chernick SS, et al: Lipoprotein lipase activity of adipose and mammary tissue and plasma triglyceride in pregnant and lactating rats. Biochim Biophys Acta 210:473-482, 1970

20. Lasunción MA, Herrera E: Effect of pregnancy on the uptake of lipoprotein triglyceride fatty acids by isolated adipocytes in the rat. Biochem Biophys Res Commun 98:227-233, 1981

21. Otway S, Robinson DS: The significance of changes in tissue clearing-factor lipase activity in relation to the lipaemia of pregnancy. Biochem J 106:677-682, 1968

22. Ramirez I, Llobera M, Herrera E: Circulating triacylglycerols, lipoproteins, and tissue lipoprotein lipase activities in rat mothers and offspring during the perinatal period: Effect of postmaturity. Metabolism 32:333-341, 1983

23. Ramos P, Martín-Hidalgo A, Herrera E: Insulin-induced upregulation of lipoprotein lipase messenger ribonucleic acid and activity in mammary gland. Endocrinology 140:1089-1093, 1999

24. Argiles J, Herrera E: Appearance of circulating and tissue ${ }^{14} \mathrm{C}$ lipids after oral ${ }^{14} \mathrm{C}$ - tripalmitate administration in the late pregnant rat. Metabolism 38:104-108, 1989

25. Machlin IJ: Vitamin E, in Machlin IJ (ed): Handbook of Vitamins. New York, NY, Dekker Marcel, 1984, pp 99-145

26. Braun JEA, Severson DL: Regulation of synthesis, processing and translocation of lipoprotein lipase. Biochem J 287:337-347, 1992

27. Barbas C, Herrera E: Lipid composition and vitamin E content in human colostrum and mature milk. J Physiol Biochem 54:167-174, 1998

28. Ortega RM, López-Sobaler AM, Andrés P, et al: Maternal vitamin $\mathrm{E}$ status during the third trimester of pregnancy in Spanish women: Influence on breast milk vitamin E concentration. Nutr Res 19:25-36, 1999

29. Macias C, Schweigert FJ: Changes in the concentration of carotenoids, vitamin A, alpha-tocopherol and total lipids in human milk throughout early lactation. Ann Nutr Metab 45:82-85, 2001
30. Del Prado M, Da Costa THM, Williamson DH: Effects of tri-iodothyronine administration on the disposal of oral $\left[1-{ }^{14} \mathrm{C}\right]$ triolein, lipoprotein lipase activity and lipogenesis in the rat during lactation and on removal of the litter. Biochem J 301:495-501, 1994

31. Del Prado $\mathbf{M}$, Ramos R, Hernández-Montes $H$, et al: Lipid content and lipoprotein lipase activity in skeletal muscle of lactating and weaned rats. J Lipid Res 34:1115-1120, 1993

32. Jensen DR, Schlaepfer IR, Morin CL, et al: Prevention of diet-induced obesity in transgenic mice overexpressing skeletal muscle lipoprotein lipase. Am J Physiol 273:R683-R689, 1997

33. Sampson DA, Jansen GR: Measurement of milk yield in the lactating rat from pup weight and weight gain. J Pediatr Gastroenterol Nutr 3:613-617, 1984

34. Munilla MA, Herrera E: A cholesterol-rich diet causes a greater hypercholesterolemic response in pregnant than in nonpregnant rats and does not modify fetal lipoprotein profile. J Nutr 127:2239-2245, 1997

35. Rupérez FJ, Barbas C, Castro M, et al: Simplified method for vitamin $\mathrm{E}$ determination in rat adipose tissue and mammary glands by high-performance liquid chromatography. J Chromatogr A 823:483487, 1998

36. Llobera M, Montes A, Herrera E: Lipoprotein lipase activity in liver of the rat fetus. Biochem Biophys Res Commun 91:272-277, 1979

37. Nilsson-Ehle P, Carlstrom S, Belfrage P: Rapid effect on lipoprotein lipase activity in adipose tissue of humans after carbohydrate and lipid intake. Scand J Clin Lab Invest 35:373-378, 1975

38. Iioka $\mathrm{H}$ : Changes in blood level of lipid peroxide and vitamin $\mathrm{E}$ during pregnancy: Clinical significance and relation to the pathogenesis of EPH gestosis. Gynecol Obstet Invest 38:173-176, 1994

39. Oller do Nascimento CM, Ilic V, Williamson DH: Re-examination of the putative roles of insulin and prolactin in the regulation of lipid deposition and lipogenesis in vivo in mammary gland and white and brown adipose tissue of lactating rats and litter-removed rats. Biochem J 258:273-278, 1989 